\title{
Level of knowledge, attitude, and behavior towards rheumatic disease among elderly in Samplangan Village, Gianyar
}

\author{
Made Nanda Hadi Wiguna ${ }^{1}$, I Wayan Darwata ${ }^{1}$, Made Dharmesti Wijaya ${ }^{{ }^{*}}$ \\ ${ }^{1}$ Faculty of Medicine and Health Sciences, Warmadewa University \\ *dharmestiwijaya@gmail.com
}

\begin{abstract}
Remarkable rises in life expectancy of Indonesians over the last decade lead to an increase in elderly population in Indonesia, along with the risk of dementia, disability, and other age-related diseases. In this nation, Rheumatic disease is the second most common health problem among the elderly. Moreover, rheumatism-related visit was ranked 3rd out of 10 major health problems in all health centers in Gianyar, Bali. Therefore, knowledge and attitude of the elderly regarding rheumatic disease are important in preventing and treating the disease. This study was aimed to determine the level of knowledge, attitude, and behavior towards rheumatic disease among elderly in Samplangan Village, Gianyar. A descriptive-quantitative design with cross-sectional approach was conducted on 106 elderly, who were selected using simple random sampling method. Data collection was done by direct interview and through validated questionnaires. The results show that in general, the level of knowledge of the respondents regarding rheumatic disease was poor. Meanwhile, both the attitude and the behaviour of the respondents towards rheumatic disease were good. Therefore, more information and counseling about rheumatic disease by the authorized health officers are required to improve the knowledge and the health status of elderly population in this area Keywords: Knowledge, Attitude and Behavior, Samplangan Village.
\end{abstract}

\section{Introduction}

The improvement of healthcare in Indonesia is progressing in a positive way, one of which is indicated by the increase of the average life expectancy of the population. The life expectancy of Indonesians increased from 67.89 years in 2010 to 73.19 years in 2018 [1]. Since the number of elderly (>60 years old) is around $7.18 \%$, Indonesia is now becoming one of the countries that has entered the era of elderly structured population. The consequence of the increase of the life expectancy is that the life span of the elderly population in Indonesia will also increase, along with the prevalences of age-related diseases [2].

The elderly are a high risk group for various medical problems, including muskuloskeletal abnormality such as rheumatic diseases that cause limitations among the elderly [3,4]. The impacts of these diseases on mental, physical, and social life of the elderly make rheumatic diseases very important in public health [5]. According to Indonesian Ministry of Health (2016), rheumatic ranks second out of the top ten health problems of elderly in Indonesia [6]. However, the increasing number of the rheumatic sufferers in Indonesia is not accompanied by the increasing of public awareness of this disease. The assumption that rheumatic disease may not pose life-threatening risks makes many Indonesians neglect this disease [7]. 
Bali was in the fourth rank of the province with the highest number of elderly population in Indonesia, with $10.3 \%$ elderly of the total population [8]. In Gianyar regency specifically, the local Public Health Office reported that the incidence of rheumatic disease based on the number of visits in 2012 was 22,562 cases, which was $8.94 \%$ of the ten major diseases in all health centers in Gianyar. In 2013, rheumatic disease sharply increased to 45,715 cases $(14.9 \%)$ and ranked third out of the ten major diseases in all health centers in Gianyar $[9,10]$. Good knowledge in understanding rheumatic disease is very important to accelerate the healing process and to reduce the risk of injury in patients with rheumatic. If a person has insufficient knowledge and poor management therapy of rheumatic disease, the possibility of disability is very large [11].

This study was aimed to estimate the level of knowledge, attitude, and behavior towards rheumatic disease among elderly in Samplangan Village, Gianyar Regency. The result of this study is expected to provide more data about the level of knowledge, attitude, and behavior of the elderly in Gianyar towards rheumatic disease to help the authorities or local government to make appropriate policies regarding this disease.

\section{Method}

A descriptive-quantitative study design with cross-sectional approach was conducted in Banjar Bukit Batu and Banjar Selat, Samplangan Village, Gianyar Regency, in September to December 2017. The target population in this study was all elderly registered in four Banjar in Samplangan Village, Gianyar, while the accessible population was all elderly registered in Banjar Bukit Batu and Banjar Selat, Samplangan Village, Gianyar.

Samples were selected from accessible population using multistage random sampling method. The first stage was the selection of two Banjar in Samplangan Village using purposive sampling technique. The second stage was the selection of sample unit using simple random sampling. Validated questionnaires were used, consisted of respondent identity and questions in three categories: knowledge, attitude, and behavior. Each of those categories has eight, ten, and five questions respectively. The data was collected using structured interview technique. The level of knowledge, attitude, and behavior of the respondent were then classified as good ( $\geq 75 \%$ questions were correct), average (56-74\% questions were correct), and poor $(\leq 55 \%$ questions were answered $)$..

\section{Results And Discussion \\ 3.1. Respondents Characteristics}

A total of 106 respondents were interviewed using validated questionnaires. The respondents characteristics data including sex, age, address (banjar), education, and occupation were obtained. The results show that most of the respondents aged 60-74 years at the time of the survey with slightly more men than women in the study sample. In addition, more than a half of the respondents had low-level education (Table 1). 
Table 1. Respondents characteristics

\begin{tabular}{|c|c|c|}
\hline Respondents Characteristics & $\mathbf{n}$ & $\%$ \\
\hline \multicolumn{3}{|l|}{ Sex } \\
\hline Male & 57 & 53.8 \\
\hline Female & 49 & 46.2 \\
\hline Total & 106 & 100.0 \\
\hline \multicolumn{3}{|l|}{ Age } \\
\hline $60-74$ years old & 90 & 84.9 \\
\hline $75-90$ years old & 16 & 15.1 \\
\hline Total & 106 & 100.0 \\
\hline \multicolumn{3}{|l|}{ Address (Banjar) } \\
\hline Bukit Batu & 66 & 62.3 \\
\hline Selat & 40 & 37.7 \\
\hline Total & 106 & 100.0 \\
\hline \multicolumn{3}{|l|}{ Level of Education } \\
\hline Low (never attended school or primary school) & 61 & 57.5 \\
\hline Moderate (secondary school) & 37 & 35.0 \\
\hline High (university) & 8 & 7.5 \\
\hline Total & 106 & 100.0 \\
\hline \multicolumn{3}{|l|}{ Occupation } \\
\hline Enterpreneurs/traders & 18 & 17.0 \\
\hline Employee & 6 & 5.7 \\
\hline Farmers and laborers & 33 & 31.0 \\
\hline Housewife & 27 & 25.5 \\
\hline Others & 22 & 20.8 \\
\hline Total & 106 & 100.0 \\
\hline
\end{tabular}

\subsection{Level of Knowledge towards Rheumatic}

The results show that $47.2 \%$ of the respondents had poor knowledge about rheumatic disease. Only $21.7 \%$ had good knowledge while $31.1 \%$ had sufficient knowledge on rheumatic disease. Therefore in general, the level of knowledge among the elderly in Samplangan Village was categorized low (53.7\%). There were some aspects that not known yet by the majority of the respondents including types of rheumatic, prevention of the disease, and its risk factors (Table 2).

Table 2. Frequency and percentage of respondents' correct answers about the aspects of knowledge

\begin{tabular}{llcc}
\hline No & \multicolumn{1}{c}{ Aspects of Knowledge } & \multicolumn{2}{c}{ Correct Answers } \\
\cline { 3 - 4 } & & $\mathbf{n}$ & $\mathbf{\%}$ \\
\hline 1 & Definition of rheumatic & 89 & 84.0 \\
2 & Etiology of rheumatic & 38 & 35.8 \\
3 & Types of rheumatic & 21 & 19.8 \\
4 & Signs and symptoms of rheumatic & 88 & 83.0 \\
5 & Risk factors of rheumatic & 38 & 35.8 \\
6 & Food that triggers rheumatic & 81 & 76.4 \\
7 & Management of rheumatic & 67 & 63.2 \\
8 & Prevention of rheumatic & 33 & 31.1 \\
& $\quad$ Total & 455 & 53.7 \\
\hline
\end{tabular}

*Total divider $\mathrm{n}=848$ 


\subsection{Level of Attitude towards Rheumatic}

This study shows that the majority of the respondents $(65.1 \%)$ had good attitude, while $29.2 \%$ had sufficient behavior and only $5.7 \%$ had poor behavior towards rheumatic. Thus in general, the level of attitude towards rheumatic disease among the elderly in Samplangan, Gianyar, was categorized good (75.8\%). The aspects of attitude that were examined can be seen in Table 3.

Table 3. Frequency and percentage of respondents' correct answers about the aspects of attitude

\begin{tabular}{llll}
\hline No & \multicolumn{1}{c}{ Aspects of Attitude } & Score & \% \\
\hline 1 & Ask the experts about how to deal with rheumatic & 380 & 89.6 \\
2 & Women must be more aware of rheumatic disease than men & 265 & 62.5 \\
3 & $\begin{array}{l}\text { Must avoid food that could trigger rheumatic such as nuts, offal, } \\
\text { and melinjo }\end{array}$ & 351 & 82.8 \\
& & 302 & 71.2 \\
4 & Spending some time to exercise is necessary & 305 & 71.9 \\
5 & Warm compress is helpful for relieving joint pain & 295 & 69.6 \\
6 & Applying oil that cools the skin and joints could relieve joint pain & 318 & 75.0 \\
7 & Rest is important to control the onset of joint pain & 342 & 80.7 \\
8 & Early detection of rheumatic is needed & 314 & 74.1 \\
9 & Examination of joint pain must be done to confirm the diagnosis & 344 & 81.1 \\
10 & Increase knowledge about rheumatic & 3,216 & 75.8 \\
\hline
\end{tabular}

*Total divider $\mathrm{n}=4240$

\subsection{Level of Behavior towards Rheumatic}

The result of this study shows that among the respondents, $40.6 \%$ had good behavior, $37.7 \%$ had sufficient behavior, and only $21.7 \%$ were scored as poor behavior. Therefore, the level of behavior towards rheumatic disease among the elderly in Samplangan, Gianyar, was categorized sufficient $(63.6 \%)$. The aspects of behavior that were examined can be seen in Table 4

Table 4. Frequency and percentage of respondents' correct answers about the aspects of behavior

\begin{tabular}{llll}
\hline No & \multicolumn{1}{c}{ Aspects of Behavior } & \multicolumn{2}{c}{ Correct Answers } \\
\cline { 3 - 4 } & & $\mathbf{n}$ & \multicolumn{1}{c}{$\%$} \\
\hline 1 & Actions taken to reduce join pain & 60 & 56.6 \\
2 & The place to go when joint pain occurs & 82 & 95.3 \\
3 & Avoiding foods that trigger rheumatic & 38 & 77.4 \\
4 & Exercice regularly & 56 & 52.8 \\
5 & Soak the feet with warm water if joint pain occurs & 337 & 63.6 \\
\hline
\end{tabular}

*Total divider $\mathrm{n}=530$

In this study, the levels of knowledge, attitude, and behavior of elderly in Samplangan Village, Gianyar Regency, were examined using cross-sectional analysis. Elderly people in Samplangan Village were sampled using simple random sampling method and interviewed using validated questionnaires. Elderly population was selected because this group is at high risk of rheumatic disease and thus the data obtained in this study might help the authorized health office to determine the right policy in decreasing the incidence of rheumatic disease in elderly. 


\subsection{Level of Knowledge of the Respondents towards Rheumatic}

This study shows that almost half of the respondents had poor knowledge about rheumatic disease. This result is in line with a similar study done in Tresna Werdha Budi Mulia Nursing Home 1 in Cipayung Jakarta. This study reports that among 100 respondents, $60 \%$ had poor knowledge about rheumatic disease while only $7 \%$ had good knowledge and 33\% had sufficient knowledge [12]. A study by Hendra (2008) explains that the level of education of a person is one of the aspects that will determine whether an individual can easily absorb and understand the information given or not [13]. In general, the higher the level of education of a person, the better his knowledge is, and the easier it is to receive information. Someone with higher education level is generally responsive about the surrounding situation including their own health. They will solve their health problems and have the desire to explore new knowledge from other sources [13].

\subsection{Level of Attitude of the Respondents towards Rheumatic}

The result shows that most of the respondents $(65.1 \%)$ had good attitude towards rheumatic disease. This result is aligned with previous research conducted by Nofriandi (2016) which shows that $64.6 \%$ of elderly respondents in Polda Balai Baru housing area, Padang, Indonesia, had a good attitude towards rheumatic disease [11]. A study by Azwar (2013) points out some factors that influence the formation of the attitude of the respondents namely knowledge, experience, influence of others, culture, sources of information, level of education, and emotional [14].

\subsection{Level of Behavior of the Respondents towards Rheumatic}

Study on the behavior of elderly in Samplangan, Gianyar shows that most of the respondents had good behavior towards rheumatic disease. This result is in line with similar study on the elderly in Parulohan Village, Lintongnihuta District, Humbang Hasundutan Regency. Among 35 respondents, $48.6 \%$ had good behavior, $37.1 \%$ had sufficient behavior, and only $14.3 \%$ had poor behavior [15].The results of interviews conducted with teacher "B" at public junior high school Yogyakarta are:

\subsection{Correlations among Level of Knowledge, Attitude, and Behavior of the Respondents towards Rheumatic}

According to Notoatmodjo (2012), knowledge is the result of knowing, which happens after doing thorough research on a particular object [16]. Knowledge comes from sensing that occurs through the five human senses: the senses of sight, hearing, smell, taste, and touch. Knowledge is needed as a support in generating confidence as well as daily attitude and behavior, and therefore knowledge is a very important domain for the formation of someone's actions [16]. Based on the results of this study, most of the well-informed people had good attitude. Respondents who have good knowledge also have good behavior, and respondents who have good attitude also have good behavior. It can be seen that knowledge, attitude, and behavior are directly proporsional in this study.

\section{Conclusions}

The level of knowledge about rheumatic disease among the elderly in Samplangan, Gianyar, in general was poor. Meanwhile, the level of attitude and behavior of the elderly was good. We observed that the elderly who have low education level and aged 75-90 years tend to have poor knowledge, attitude, and behavior towards this disease. Therefore, more intensive counseling by the authorized health officers or medical team is necessary to raise the level of 
knowledge, attitude, and behavior of the elderly and reduce the incidence of rheumatic disease in the community.

\section{References}

[1] Badan Pusat Statistik. Angka Harapan Hidup (AHH) menurut Provinsi dan Jenis Kelamin tahun $2010 \quad-2018.2019 . \quad$ Available from https://www.bps.go.id /linkTableDinamis/view/id/1114 (Accessed: 2019, April 20)

[2] Brown GC. Living too long: the current focus of medical research on increasing the quantity, rather than the quality, of life is damaging our health and harming the economy. EMBO Rep. 2014;16(2):137-141. doi:10.15252/embr.201439518

[3] Falsarella, G. R., Coimbra, I. B., Barcelos, C. C., Costallat, L.T., Carvalho, O.M., and Coimbra, A.M. Prevalence and factors associated with rheumatic diseases and chronic joint symptoms in the elderly. Geriatr Gerontol Int. 2013 Oct; 13(4): 1043-50. doi: 10.1111/ggi.12052. Epub 2013 Mar 19.

[4] Helmick, C. G., Felson, D. T., Lawrence, R. C., Gabriel, S., Hirsch, R., Kwoh, C. K. Estimates of the prevalence of arthritis and other rheumatic conditions in the United States. Part I. Arthritis Rheum 2008; 58: 15-25.

[5] Zangi, H.A., Finset, A., Steen, E., Mowinkel, P., Hagen, K.B. The effects of a vitality training programme on psychological distress in patients with inflammatory rheumatic diseases and fibromyalgia: a 1-year follow-up. Scand J Rheumatol 2009; 38: 231-234

[6] Kementerian Kesehatan RI. Situasi Lanjut Usia di Indonesia. Jakarta Selatan: Pusat Data dan Informasi. 2016; 5. Available from : http://www.depkes.go.id /resources/download/pusdatin/infodatin/infodatin\%20lansia\%202016.pdf (Accessed: 2017, November 1).

[7] Muchid A. Pharmaceutical Care Untuk Pasien Penyakit Arthritis Rematik. Jakarta: Departemen Kesehatan. 2006. Available from: http://binfar.kemkes.go.id /2013/02/pharmaceutical-care-untuk-pasien-penyakit-arthritis-rematik/\#.WGo8I1 N9600 (Accessed: 2016, Desember 8).

[8] Dinkes Provinsi Bali. Profil Kesehatan Provinsi Bali 2015. Dinas Kesehatan Provinsi Bali, Denpasar. 2016. Available from : http://www.diskes.baliprov.go.id /files/subdomain/diskes/Profil\%20Kesehatan\%20Provinsi\%20Bali/Tahun\%202015/Bali_ Profil_2015.pdf (Accessed: 2016, Desember 7).

[9] Dinkes Kabupaten Gianyar. Profil Kesehatan Kabupaten Gianyar 2012. Dinas Kesehatan Kabupaten Gianyar. 2013. Available from : http://www.diskes.baliprov.go.id/files /subdomain/diskes/Profil\%20Kesehatan\%20Provinsi\%20Bali/Tahun\%202012/Bali_ kab.gianyar_profil_2012.pdf (Accessed: 2016, Desember 7).

[10]Dinkes Kabupaten Gianyar. Profil Kesehatan Kabupaten Gianyar 2013. Dinas Kesehatan Kabupaten Gianyar. 2014. Available from : http://www.diskes.baliprov.go.id /files/subdomain/diskes/Profil\%20Kesehatan\%20Provinsi\%20Bali/Tahun\%202013/Bali_ kab.gianyar_profil_2013.pdf (Accessed: 2016, Desember 7).

[11] Nofriandi, D. Gambaran Tingkat Pengetahuan dan Sikap Lansia Tentang Rheumatoid Arthitis di Posyandu Lansia Komplek Perumahan Polda Balaibaru Wilayah Kerja Puskesmas Belimbing Padang. Skripsi. Padang: Program Studi Ilmu Keperawatan, Universitas Andalas Padang. 2016. Available from : http://scholar.unand.ac.id/12210/ (Accessed: 2016, Desember 7).

[12] Afriyanti, F. Tingkat Pengetahuan Lansia tentang Penyakit Rheumatoid Arthritis di Panti Sosial Tresna Werdha (PSTW) Budi Mulia 1 Cipayung Jakarta Tahun 2009. Skripsi. Jakarta: Program Studi Ilmu Keperawatan, Universitas Islam Negeri Syarif Hidayatullah Jakarta. 2009. Available 
/8817992/Tingkat_Pengetahuan_Lansia_tentang_Reumathoid_Artritis (Accessed: 2016, Desember 7).

[13] Hendra, AW. Faktor-Faktor Yang Mempengaruhi Pengetahuan. Jakarta: Pustaka Sinar Harapan. 2008.

[14] Azwar, S. Sikap Manusia Teori dan Pengukurannya. Yogyakarta : Pustaka Pelajar Offset. 2013.

[15] Simamora ACR. Hubungan Pengetahuan dan Perilaku Lansia Terhadap Pencegahan Peningkatan Asam Urat di Poskesdes Desa Parulohan Kecamatan Lintongnihuta Kabupaten Humbang Hasundutan Tahun 2016. Jurnal ilmiah PANNMED: 1; 42-46. 2016. Available from :http://pannmed.poltekkesmedan.ac.id/files/2016/Vol.11_adelima.pdf(Accessed:2017,Novemb er 11).

[16] Notoatmodjo, S. Pendidikan dan Perilaku Kesehatan. Jakarta: Rineka Cipta. 2012. 